\title{
ALIH FUNGSI LAHAN DI PERKOTAAN (STUDI KASUS DI KOTA BANDUNG DAN YOGYAKARTA)
}

\author{
Urban Land Misuse: \\ (A Case Study of Bandung City and Yogyakarta City)
}

Rohani Budi Prihatin

\author{
Pusat Pengkajian, Pengolahan Data dan Informasi (P3DI) \\ Sekretariat Jenderal DPR RI
}

Naskah diterima: 11 September 2015

Naskah dikoreksi: 15 November 2015

Naskah diterbitkan: 23 Desember 2015

\begin{abstract}
Over the past four decades the cities and towns of Indonesia have experienced dramatic population growth. Population growth makes crisis in land use and agriculture that could undermine the health, security, and sustainability of those cities. The purpose of this study is to determine the land use patterns and its changes over time in Bandung City and Yogyakarta City. The research has been done in 2014, by using qualitative method. By considering urbanization and demographic aspect, this study concludes that decision maker in those cities are inconsistent in implementing Regional Development and Spatial Planning. Generally, local city tempted to allocate land use for housing and real estate for short term reasons.
\end{abstract}

Keywords: Urbanization, land use, Bandung City, Yogyakarta City.

\begin{abstract}
Abstrak: Lebih dari empat dekade, kota-kota di Indonesia mengalami pertumbuhan penduduk yang dramatis. Pertumbuhan penduduk ini mengakibatkan krisis penggunaan lahan serta pertanian yang berdampak pada kesehatan, keamanan, dan keberlanjutan kota-kota tersebut. Tulisan ini membahas mengenai pola penggunaan lahan dan perubahan perubahannya sepanjang waktu di Kota Bandung dan Kota Yogyakarta. Penelitian dilakukan pada tahun 2014 dengan menggunakan pendekat an kualitatif. Dengan memerhatikan aspek demografi dan urbanisasi, studi ini menyimpulkan bahwa selama ini terjadi ketidakkonsistenan pemerintah daerah dalam mempertahankan desain wilayah sebagaimana yang telah ditetapkan dalam Rencana Tata Ruang Wilayah (RTRW). Umumnya pemerintah daerah tergoda untuk mengalokasikan lahan permukiman atau perumahan real estate karena alasan jangka pendek.
\end{abstract}

Kata kunci: Urbanisasi, penggunaan lahan, Kota Bandung, Kota Yogyakarta.

\section{Pendahuluan}

Permasalahan umum yang dihadapi oleh kota besar di Indonesia adalah pertumbuhan jumlah penduduk perkotaan yang tinggi. Penyebabnya adalah pertumbuhan penduduk alamiah dan faktor urbanisasi. Kedua faktor penyebab ini pada akhirnya berdampak lahirnya berbagai persoalan di perkotaan seperti kurangnya ruang untuk kebutuhan perumahan.

Implikasi lain dari meningkatnya kebutuhan ruang di perkotaan adalah tingginya permintaan lahan. Penyediaan lahan di pusat kota semakin terbatas dan tentu sangat mahal sehingga perkembangan perkotaan cenderung "mencaplok" wilayah pinggiran perkotaan.

Secara umum, setiap pertambahan jumlah penduduk akan disertai dengan tuntutan pertambahan kebutuhan dasar (pangan, sandang, dan papan). Kebutuhan akan pangan dan sandang biasanya berasal dari produksi pertanian, sedangkan kebutuhan bahan perumahan umumnya berasal dari sumberdaya alam.

Indonesia memiliki jumlah penduduk yang besar. Jumlah ini terus akan bertambah setiap tahunnya. ${ }^{1}$ Data BPS (2005) menyebutkan bahwa tingkat kepadatan penduduk Indonesia pada tahun 2000 adalah 108 jiwa per kilometer persegi, jumlah ini terus meningkat menjadi 116 orang per kilometer persegi pada tahun 2005.

Pertumbuhan penduduk yang begitu cepat, serta aktivitas pembangunan dalam berbagai bidang akan menyebabkan meningkatnya permintaan lahan. Hal inilah yang akan mendorong terjadinya alih fungsi lahan pertanian ke non pertanian.

\footnotetext{
Menurut data Badan Pusat Statistik (BPS), laju pertumbuhan penduduk di Indonesia sekitar tiga juta hingga empat juta per tahun (atau sekitar 1,49 persen). Lihat http://www.datastatistik-indonesia.com/portal/ index.php? option $=$ com_content\&task $=v i e w \& i d=919$, diakses 11 Agustus 2013.
} 
Menurut Arsyad dan Rustiadi (2008:78) konversi lahan merupakan konsekuensi logis dari peningkatan aktivitas dan jumlah penduduk serta proses pembangunan lainnya. Konversi lahan pada tahap tertentu wajar terjadi, namun pada sisi lain jika tidak dikendalikan maka akan semakin bermasalah karena umumnya alih fungsi terjadi di atas lahan pertanian yang masih produktif.

Semakin sempitnya lahan pertanian di perkotaan dan pinggir perkotaan akibat alih fungsi lahan akan memengaruhi sisi ekonomi, sosial, dan lingkungan masyarakat tersebut. Jika fenomena alih fungsi lahan pertanian ke nonpertanian terus terjadi secara tak terkendali, maka hal ini akan menjadi ancaman tidak hanya bagi petani dan lingkungan, tetapi hal ini bisa menjadi masalah nasional.

Harus diakui, orientasi pembangunan selama ini lebih menitikberatkan daerah perkotaan. Di Provinsi Daerah Istimewa Yogyakarta (selanjutnya disingkat DIY) misalnya, setiap tahun lahan pertanian menyusut sekitar 250 hektar. Besaran luas alih fungsi lahan yang mencapai angka 2,3\% per tahun untuk Kabupaten Sleman dan 7\% per tahun untuk Kota Yogyakarta merupakan angka yang cukup besar dan perlu disikapi secara kritis (Harian Kedaulatan Rakyat, 11 April 2006).

Perkembangan wilayah yang tidak terkendali akan memacu terjadinya alih fungsi lahan dari pertanian ke nonpertanian yang konsekuensinya bertolak belakang dengan upaya mempertahankan swasembada pangan dan sustainable development. Jika tidak hati-hati, alih fungsi lahan pertanian yang tidak terkendali akan menjadi ancaman bagi ketahanan pangan pada level daerah, provinsi, atau bahkan nasional.

Data Badan Pertanahan Nasional (BPN) tahun 2007, luas sawah di Jawa adalah 4,1 juta hektar. Namun berdasarkan audit Kementerian Pertanian melalui citra Landsat pada 2010, hanya tersisa 3,5 juta hektar. UU tentang Perlindungan Lahan Pertanian Pangan Berkelanjutan dianggap mandul karena belum ada penetapan oleh pemerintah daerah, tentang mana wilayah pertanian yang boleh dikonversi dan mana yang tidak boleh.

Data BPS (1997) mengungkapkan bahwa 48,3 persen luas areal panen padi di Indonesia berada di Pulau Jawa. Areal ini menghasilkan 27,9 juta ton atau 56,5 persen dari total padi yang dihasilkan oleh Indonesia.

Praktik di lapangan menunjukkan bahwa alih fungsi lahan akan terus terjadi meski UU tentang Perlindungan Lahan Pertanian Pangan Berkelanjut an sudah lama ditetapkan. Implementasi UU itu sangat tergantung pada komitmen kepala daerah. Kecenderungan memperlihatkan setelah ditetapkan rencana tata ruang, luas lahan tanaman pangan di sejumlah kabupaten justru menurun. Hal ini karena Kepala Daerah lebih tertarik investasi jangka pendek nonpertanian. Pemerintah Pusat juga ikut menyusutkan lahan subur dengan membangun infrastruktur seperti jalan tol di Jawa yang melewati wilayah sawah beririgasi.

Alih fungsi lahan pertanian merupakan ancaman terhadap pencapaian ketahanan dan kedaulatan pangan. Implikasinya sangat serius terutama terhadap produksi pangan, lingkungan fisik, serta tingkat kesejahteraan petani perdesaan yang kehidupannya bergantung pada lahannya. Fenomena ini kurang diimbangi oleh upaya-upaya terpadu untuk mengembangkan lahan pertanian melalui pencetakan lahan pertanian baru yang potensial.

Di sisi lain, alih fungsi lahan pertanian pangan juga menyebabkan semakin sempitnya luas lahan yang diusahakan dan sering berdampak pada menurunnya tingkat kesejahteraan petani. Oleh karena itu, pengendalian alih fungsi lahan pertanian pangan melalui perlindungan lahan pertanian pangan merupakan salah satu upaya untuk mewujudkan ketahanan dan kedaulatan pangan, dalam rangka meningkatkan kemakmuran dan kesejahteraan petani dan masyarakat pada umumnya.

Di sisi lain, proses urbanisasi yang tidak terkendali juga berdampak pada meluasnya aktivitas-aktivitas perkotaan yang makin mendesak aktivitas-aktivitas pertanian di kawasan perdesaan yang berbatasan langsung dengan perkotaan. Fenomena ini juga berkaitan dengan hilangnya akses penduduk perdesaan pada sumber daya utama yang dapat menjamin kesejahteraannya dan hilangnya mata pencarian penduduk agraris. Konsekuensi logisnya adalah terjadinya migrasi penduduk perdesaan ke perkotaan dalam jumlah yang besar tanpa diimbangi ketersediaan lapangan kerja di perkotaan.

Perlindungan lahan pertanian pangan merupakan bagian yang tidak terpisahkan dalam penataan ruang wilayah. Untuk itu, perlindungan lahan pertanian pangan perlu dilakukan dengan menetapkan kawasan-kawasan pertanian pangan yang perlu dilindungi. Kawasan pertanian pangan merupakan bagian dari penat aan kawasan perdesaan pada wilayah kabupaten. Dalam kenyataannya lahan-lahan pertanian pangan berlokasi di wilayah kota juga perlu mendapat perlindungan. Perlindungan kawasan pertanian pangan dan lahan pertanian pangan meliputi perencanaan dan penetapan, pengembangan, penelitian, pemanfaat an dan pembinaan, pengendalian, pengawasan, 
pengembangan sistem informasi, perlindungan dan pemberdayaan petani, peran serta masyarakat, dan pembiayaan. Perlindungan kawasan dan lahan pertanian pangan dilakukan dengan menghargai kearifan budaya lokal serta hak-hak komunal adat.

Terkonsentrasinya pembangunan di perkotaan, di satu sisi menambah lapangan kerja di sektor nonpertanian, akan tetapi juga menimbulkan dampak negatif yang kurang menguntungkan. Dampak negatif tersebut antara lain berkurangnya luas sawah yang mengakibatkan turunnya produksi padi, yang mengganggu tercapainya swasembada pangan dan timbulnya kerawanan pangan serta mengakibatkan bergesernya lapangan kerja dari sektor pertanian ke nonpertanian. Apabila tenaga kerja tidak terserap seluruhnya, maka akan meningkatkan angka pengangguran. Semua hal ini perlu mendapatkan perhatian khusus dari semua pihak, agar perkembangan perkotaan di kemudian hari tidak menuju situasi unmanaged growth.

Berdasarkan rumusan masalah tersebut maka pertanyaan penelitian yang akan dianalisis dalam tulisan ini adalah (1) Faktor-faktor apa saja yang mendorong terjadinya alih fungsi lahan pertanian menjadi lahan nonpertanian? (2) Regulasi apa saja yang sudah ditetapkan oleh Pemerintah Pusat dan Pemerintah Daerah dalam mengendalikan alih fungsi lahan tersebut? (3) Apakah regulasi pengendalian alih fungsi lahan tersebut berlaku efektif?

\section{Teori Perebutan Ruang Kota}

Perebutan ruang di perkotaan merupakan cerita utama dalam proses pembangunan kota. Meningkatnya intensitas penetrasi kapital demi memuluskan investasi yang diyakini mampu mewujudkan kesejahteraan rakyat, mengakibatkan tersingkirnya ruang-ruang publik.

Dengan meminjam analisis dari Marx, Basundoro (2012) menyebut bahwa perebutan ruang di perkotaan merupakan bagian dari perebutan alat-alat produksi.

Kondisi itu terjadi beriringan dengan pertambahan penduduk dan kegiatan pembangunan sehingga meningkatkan permintaan lahan. Hal ini sesuai dengan prinsip ekonomi bahwa pemilik lahan selalu akan memaksimalkan penggunaan lahannya. Kegiatan-kegiatan yang dianggap tidak produktif dan tidak menguntungkan akan ditinggalkan dan digantikan dengan kegiatan yang lebih produktif dan menguntungkan.

Proses semacam ini hampir melanda semua kota di dunia dimana kenaikan jumlah penduduk kota tidak terkendali, dan tidak diikuti kebijakan untuk membagi ruang kota secara adil dan legal.
Pembagian ruang kota secara adil mustahil dilakukan manakala kota hanya memiliki ruang yang amat terbatas sementara ruang tersebut tidak ubahnya sebagai sebuah komoditi. Dalam hukum komoditi maka siapa yang memiliki modal yang lebih besar dan lebih baik, apapun bentuknya, maka dialah yang akan berhasil menguasai ruang tersebut.

Secara umum, kota-kota di Indonesia tidak dirancang untuk menerima para pendatang dalam skala besar karena ruang kota memang serba terbatas. Terbatasnya ruang kota membawa konsekuensi bahwa penggunaan ruang yang berlangsung secara terus-menerus akan melibatkan ketegangan di antara sejumlah kelompok kepentingan karena tingginya permintaan akan ruang baik oleh perorangan maupun oleh kelompok tertentu. Oleh karena itu konflik yang menyangkut penggunaan lahan di perkotaan dapat timbul dengan mudah.

Freek Colombijn (2010), antropolog dari Vrije Universiteit Amsterdam mengemukakan bahwa persaingan untuk mendapatkan ruang di sini dianggap sebagai suatu perlombaan dan hadiahnya adalah ruang tersebut. Tidak semua pemain at au tim dalam perlombaan ini sama pentingnya. Kelompokkelompok yang paling strategis adalah yang paling berpengaruh, sedangkan sebagian besar anggota masyarakat yang lainnya harus menyesuaikan diri dengan keadaan supaya mereka dapat menemukan ruang bagi mereka.

Persaingan mendapatkan ruang biasanya melibatkan hampir semua unsur yang menginginkan atau berkepentingan. Menurut Ramlan Surbakti sebagaimana dikutip oleh Basundoro (2013), untuk kasus-kasus kontemporer perebutan ruang kota secara umum terjadi antara pemerintah kota dengan masyarakat, yang polanya cukup beragam. Dalam kasus di Indonesia, Ramlan (dalam Basundoro 2012) mengelompokkan pola perebutan ruang kota menjadi delapan kategori umum, yaitu:

1. Pemerintah kota dengan warga yang timbul karena perubahan peruntukan tanah yang tidak transparan;

2. Pemerintah kota dengan perusahaan swasta akibat tindakan swasta menyerobot tanah milik pemerintah kota;

3. Warga dengan investor;

4. Pemerintah kota dengan warga karena pembangunan fasilitas umum;

5. Pemerintah kota dengan legislatif karena pengalihan lahan tanpa persetujuan kedua belah pihak;

6. Warga, investor, dan pemerintah kota (berdimensi segi tiga); 
7. Warga dengan developer berkaitan dengan pembangunan fasilitas umum di pemukiman; dan

8. Perebutan ruang karena prosedur administrasi yang salah.

Prins dan Nas dalam artikelnya yang berjudul "The Struggle for The Third World City" yang dikutip dalam Basundoro (2013) mengemukakan bahwa semua kegiat an manusia harus menggunakan ruang. Hubungan-hubungan sosial dibangun di atas landasan struktur ruang (spatial structure), dan hubungan-hubungan ini selalu dilanda ketegangan, demikian juga struktur ruang.

Pemikiran-pemikiran tersebut di atas menjadi landasan dasar dalam menganalisis penggunaan ruang-ruang perkotaan. Semakin banyak individu atau kelompok ingin mengakses ruang yang sama, maka semakin tinggi ketegangan yang melanda kawasan ruang tersebut. Jika kota diasumsikan sebagai ruang yang paling banyak diminati oleh manusia maka ketegangan di kota jauh lebih besar dan lebih intensif jika dibandingkan dengan tempat lain.

\section{McKenzi dalam Gottdiener (2010)} mengistilahkan proses perebutan ruang kota sebagai invasi atas ruang. Menurutnya, proses invasi dibagi dalam tiga tingkatan, yaitu initial stage (tahap permulaan), secondary stage (tahap lanjutan), dan climax stage (tahap klimaks).

Proses permulaan invasi ditandai adanya gejala ekspansi geografis dari satu grup sosial dan kemudian menemui tantangan dari penduduk yang ada pada daerah yang terkena ekspansi. Pada tahap lanjutan, persaingan semakin seru yang kemudian diikuti proses displacement (perpindahan), selection (seleksi) dan assimilation (asimilasi).

Intensitas proses displacement, selection, assimilation sangat ditentukan oleh sifat yang mengekspansi maupun yang diekspansi. Kelompokkelompok yang terpaksa kalah bersaing akan menempati/mengadakan ekspansi ke wilayah lain yang lebih lemah dan kemudian akan diikuti oleh suksesi baru.

Sementara pada tahap terakhir yaitu tahapan klimaks terjadi manakala telah tercapai equilibrium (keseimbangan) antarkelompok-kelompok yang saling bersaing untuk mendapatkan ruang tersebut. Equilibrium dapat tercapai ketika semua kelompok sudah mendapatkan bagiannya masing-masing dari ruang yang diperebutkan tersebut, walaupun hal tersebut sangat sulit terwujud.

Pada masa-masa mendatang konflik-konflik terkait perebutan ruang perkotaan akan terus mengalami peningkatan. Hal tersebut terkait erat dengan, pertama, jumlah penduduk kota-kota besar di Indonesia dari tahun ke tahun yang juga mengalami peningkat an tajam. Kenaikan penduduk ini selain dipicu oleh kenaikan penduduk alamiah (natalitas berbanding mortalitas) juga karena tekanan urbanisasi. Setiap hari peristiwa kelahiran terus-menerus terjadi di perkotaan. Pada saat yang sama, jumlah orang-orang desa yang ingin mengadu nasib di kota-kota besar juga terus mengalami peningkatan.

Kenaikan jumlah penduduk di Bandung dan Yogyakarta yang drastis membawa dampak serius bagi ketersediaan ruang karena setiap pertambahan penduduk pasti memerlukan penambahan ruang. Padahal, ruang di kota tidak pernah bisa ditambah karena bumi tidak pernah bisa memperluas dirinya. Konsekuensi lebih lanjut dari kondisi tersebut adalah jatah setiap orang akan ruang kota akan semakin mengecil dan menyempit.

Secara umum, pemanfaatan dan penggunaan lahan di perkotaan seringkali mengabaikan perencanaan ruang dan tata bangunan yang telah disiapkan. Akibatnya terjadi ketidakteraturan fungsi, estetika, sirkulasi dan pergerakan transport asi yang tidak lancar, juga intensitas ruang yang tidak seimbang yang berimplikasi terhadap penurunan kualitas lingkungan.

Proses urbanisasi yang tidak terkendali pada akhirnya menyebabkan ketidakseimbangan demografi secara keruangan. Fenomena ini sering disebut dengan istilah urbanisasi berlebih atau overurbanization. Dalam istilah lain sering disebut sebagai urbanisasi semu atau pseudourbanization.

Berkenaan dengan hal tersebut di atas, Smith dan Nemeth (1988) menyatakan bahwa urbanisasi harus dikendalikan, sebab jika tidak maka menimbulkan dampak negatif baik terhadap penduduk kota, penduduk pedesaan, maupun pengaruh makro terhadap negara. Sebaliknya, jika proses urbanisasi bisa dikendalikan akan memberikan dampak positif.

Laporan Bank Dunia (1994) yang dikutip oleh Keban (1996) menyebutkan ada hubungan positif antara tingkat urbanisasi di suatu negara dengan tingkat pendapatan per kapita. Korelasi positif tersebut telah didukung dengan data empiris sehingga memberikan keyakinan bahwa urbanisasi mempunyai peranan penting dalam pembangunan, artinya peningkatan urbanisasi dapat mempercepat pembangunan.

Pada dasarnya, penduduk merupakan modal dasar pembangunan. Jumlah penduduk yang besar, pada satu sisi, merupakan potensi pembangunan, namun jumlah penduduk yang banyak tapi tidak berkualitas maka itu merupakan ancaman bagi 
pembangunan. Berdasarkan prinsip ini, jika suatu wilayah memiliki tingkat pertumbuhan penduduk yang tinggi maka perlu dilakukan upaya penanganan pengendalian dan peningkatan kualitas agar tidak menjadi beban bagi proses pembangunan.

Problem daerah perkotaan yang sulit dicarikan solusinya adalah migrasi penduduk dari desa ke kota. Secara umum, migrasi penduduk di Provinsi Jawa Barat tentunya berpengaruh terhadap tingkat kepadatan penduduk perkotaan. Hasil data Susenas tahun 2003 diketahui bahwa daerah yang bertipologi perkotaan mempunyai kepadatan penduduk yang tinggi seperti: Kota Bandung (13.258 orang per $\mathrm{km}^{2}$ ), Kota Bekasi (9.154 orang per km²), Kota Cirebon (7.298 orang per km²), Kota Bogor ( 7.030 orang per $\mathrm{km}^{2}$ ), dan Kota Sukabumi (5.528 orang per $\mathrm{km}^{2}$ ).

Tingginya pertumbuhan jumlah penduduk perkotaan di Indonesia, memberikan konsekuensi meningkatnya permintaan sarana dan prasarana kota (Irianto, 2008). Perkembangan cepat suatu kota dipastikan menyebabkan terjadinya perubahan pemanfaatan ruang. Hal ini dikarenakan tanah merupakan sumber daya yang terbatas. Dengan demikian, cepat atau lambat, dengan meningkatnya laju pertumbuhan penduduk dan urbanisasi, berbagai penggunaan lahan di perkotaan akan mulai saling bertentangan.

Salah satu permasalahan yang dominan yang dihadapi oleh hampir seluruh wilayah kota di Indonesia adalah semakin berkurangnya ruang publik. Ruang publik atau ruang terbuka merupakan wahana interaksi sosial yang dapat menciptakan karakter masyarakat suatu kota. Ditinjau dari bentuk fisiknya, ruang terbuka hijau, baik publik maupun privat, merupakan bagian dari ruang publik.

Lebih lanjut, upaya-upaya pelestarian fungsi lingkungan seharusnya dilakukan dengan menyisihkan sebagian ruang kota, terutama di wilayah-wilayah yang rawan bencana, harus segera dilaksanakan. Artinya ruang-ruang yang rawan tersebut dari awalnya memang bukan diproyeksikan untuk pemukiman ataupun sarana dan prasarana fisik kota, seperti sungai, danau, dam laut, ataupun mendirikan bangunan pada lereng yang relatif curam.

Kota pada umumnya berawal dan berkembang dari sebuah wilayah yang subur. Hal tersebut dapat dipahami karena pada wilayah yang subur terjadi pertemuan antarberbagai kepentingan manusia. Semakin lama kondisi wilayah perkotaan semakin semrawut sehingga dibutuhkan pengaturan, penataan, serta dukungan fasilitas sarana prasarana. Lambat laun ruang kota terus berkembang dan mengekspansi wilayah-wilayah di sekitarnya, bahkan terkadang melampaui batas administrasinya.

Menurut Slamet Hayono (2009:17), pengertian konversi, alih fungsi atau mutasi lahan secara umum menyangkut transformasi dalam pengalokasian sumber daya lahan dari suatu penggunaan ke penggunaan lainnya. Namun sebagai suatu terminologi dalam kajian land economics, pengertiannya terutama difokuskan pada proses dialihgunakannya lahan, dari lahan pertanian atau perdesaan ke penggunaan nonpertanian. Proses alih fungsi lahan ini melibatkan baik reorganisasi struktur fisik kota secara internal maupun ekspansinya ke arah luar kota.

Sejak beberapa dekade yang lalu, telah muncul pandangan ahli perkotaan seperti Kivell (1993) yang berpendapat bahwa lahan atau tanah diperlakukan sebagai komoditas strategis. Berbeda dengan komoditas lain, lahan mempunyai karakteristik yang kompleks, yaitu: (1) penyediaannya bersifat tetap; (2) tidak ada biaya penyediaan; (3) bersifat unik atau irreplaceable; (4) tidak dapat dipindahkan; dan (5) permanen.

Fenomena konversi lahan pertanian ke penggunaan nonpertanian secara teoritis dapat dijelaskan dalam konteks ekonomika lahan yang menempatkan sumber daya lahan sebagai faktor produksi. Karena faktor-faktor itu memiliki karakteristik tertentu, maka secara alamiah akan terjadi perubahan dalam penggunaan lahan untuk berbagai aktivitas. Dalam kondisi inilah akan terjadi perubahan dalam penggunaan lahan yang mengarah pada aktivitas yang mempunyai land rent yang paling tinggi. Menurut Lutfi Nasution (1991), secara teoritis dikenal 5 jenis rente tanah, yaitu rent Ricardian, rent lokasi, rent lingkungan, rent sosial, dan rent politik. Dalam kondisi pasar lahan sempurna, harga lahan haruslah mencakup kelima jenis rent tersebut.

Secara sederhana dapat dikatakan bahwa persediaan lahan bersifat tetap sedangkan permintaannya terus tumbuh dengan cepat terutama di kawasan perkotaan. Pertumbuhan kebutuhan lahan tersebut didorong oleh pertumbuhan penduduk dan aktivitas sosial-ekonomi yang menyertainya. Interaksi antara permintaan dan penawaran lahan ini akan menghasilkan pola penggunaan lahan yang mengarah pada aktivitas paling menguntungkan. Dalam konteks inilah, fenomena alih fungsi lahan pertanian ke penggunaan lahan nonpertanian terjadi.

Alih fungsi lahan pertanian dewasa ini telah menjadi isu global, tidak saja di negara berkembang yang pertaniannya masih menjadi 
sektor dominan, tetapi juga di negara-negara maju. Kivell (1993) menggambarkan bagaimana lahan menjadi faktor kunci dalam kaitannya dengan pola dan proses perubahan kota. Hal ini karena terdapat kaitan yang erat antara penggunaan lahan dan perubahan demografis di kawasan perkotaan yang dapat ditunjukkan dalam ukuran konsumsi lahan perkotaan marjinal per peningkatan rumah tangga.

Menurut Pond dan Yeates (1993), perhatian terhadap semakin berkurangnya lahan perdesaan yang subur untuk pengembangan perkotaan didasarkan pada dua anggapan. Pertama adalah lahan pertanian yang subur di wilayah yang secara klimatologis baik, secara cepat diambil alih oleh pertumbuhan perkotaan. Hal ini berarti akan memperbesar ketergantungan terhadap impor produk pertanian. Kedua, perhatian ini timbul dari kepercayaan bahwa dimasa yang akan datang teknologi pertanian secara intensif yang bertumpu pada faktor kimiawi dan irigasi akan berkurang dan mengarah kepada teknologi pertanian yang ramah lingkungan.

Dalam prosesnya, konversi lahan pertanian senantiasa berkaitan erat dengan ekspansi atau perluasan kawasan perkotaan sebagai wujud fisik dari proses urbanisasi. Menurut Lockeretz (1989), ekspansi kawasan perkotaan akan mempunyai dampak baik langsung maupun tidak langsung terhadap wilayah perdesaan sekitarnya, yaitu dalam bentuk konversi lahan pertanian dan peningkatan penduduk nonpertanian atau akibat sekunder berkurangnya lahan pertanian.

Selanjutnya di negara-negara Asia yang pertaniannya masih menjadi sektor dominan, konversi lahan pertanian menjadi salah satu isu penting dalam beberapa dekade terakhir, terutama dalam kaitannya dengan pembangunan pertanian/ perdesaan. Munculnya fenomena konversi lahan pertanian di Asia, umumnya terkait erat dengan tidak sesuainya perencanaan, implementasi yang kurang, dan kegagalan dalam manajemen penggunaan lahan. Sementara di pihak lain, terdapat juga permasalahan peningkatan jumlah penduduk, kegagalan dalam pengembangan kesempatan kerja dan ekonomi perdesaan yang kemudian berakibat terhadap peningkatan kemiskinan.

Di negara-negara yang sedang berkembang, termasuk Indonesia, terjadi konversi masif dari pertanian subur ke penggunaan nonpertanian terutama dalam wilayah yang dipengaruhi pertumbuhan pusat-pusat perkotaan yang sangat pesat. Dalam perspektif makro, di negara-negara yang sedang berkembang, fenomena konversi lahan pertanian terjadi dalam konteks transformasi struktural perekonomian dan demografis.
Transformasi struktural dalam perekonomian, dari semula yang bertumpu pada pertanian ke arah yang lebih bersifat industri, serta pert umbuhan penduduk perkotaan yang pesat akan mengakibatkan konversi dari penggunaan perdesaan-pertanian ke penggunaan nonpertanian yang luar biasa.

Kasus konversi lahan di negara-negara Asia menunjukkan fakta bahwa konversi penggunaan lahan berkaitan erat dengan penggunaan lahan, yaitu perluasan kawasan perkotaan; berkurangnya lahan pertanian subur; lahan sebagai objek spekulasi yang penggunaannya disalahgunakan. Oleh karena umumnya terjadi di wilayah perdesaan, maka masalah konversi lahan pertanian akan terkait erat dengan pembangunan perdesaan.

Menurut Pierce (1981), konsumsi terhadap lahan merupakan manifestasi dari kekuatankekuatan demografis dan ekonomi. Selain kedua kekuatan ini memberikan dorongan terhadap konversi lahan, sejumlah faktor lain juga memberikan pengaruhnya. Dari banyak faktor yang mungkin, terdapat tujuh variabel yang secara konseptual berpengaruh, yaitu perubahan penduduk, fungsi ekonomi yang dominan, ukuran kota, rata-rata nilai lahan residensial, kepadatan penduduk, wilayah geografis, dan kemampuan lahan untuk pertanian.

Dalam perspektif lain, menurut Lyon yang dikutip B. Setiawan dan A. Purwanto (1994), terdapat tiga faktor eksternal yang memengaruhi proses konversi lahan, yaitu: (1) tingkat urbanisasi; (2) situasi perekonomian makro; dan (3) kebijakan dan program pembangunan pemerintah.

Fujita (1989) memperkenalkan sebuah pendekatan yang disebut bid rent function approach. Bila dilacak secara literatur, pendekatan ini sebenarnya merujuk pada teori penggunaan lahan pertanian yang diperkenalkan oleh von Thunen (1826). Selain itu, pendekatan Fujita juga berhubungan dengan pendekatan dualitas (duality approach) ekonomi mikro modern.

Meningkatnya jumlah penduduk perkotaan serta meningkatnya tuntutan kebutuhan kehidupan dalam aspek politik, perekonomian, sosial budaya dan teknologi telah mengakibatkan meningkatnya kegiatan penduduk perkotaan yang akan berdampak pada meningkatnya kebutuhan ruang perkotaan yang besar.

Oleh karena ketersediaan ruang di dalam kota tetap dan terbatas, maka peningkatan kebutuhan ruang untuk tinggal dan kedudukan fungsi-fungsi selalu akan mengambil ruang di daerah pinggiran kota. Gejala pengambilalihan nonurban oleh penggunaan lahan urban di daerah pinggiran kota disebut invasion. Sementara itu, proses perembetan 
kenampakan fisik perkotaan ke arah keluar disebut dengan urban sprawl.

Pemerintah Indonesia telah memutuskan untuk memilih industrialisasi sebagai sebuah strategi pembangunan untuk meningkatkan pertumbuhan ekonomi nasional. Sebelum mengalami krisis ekonomi dan krisis moneter, proses industrialisasi di Indonesia berjalan cepat. Cepatnya proses industrialisasi ini, khususnya di Pulau Jawa, sangat berpengaruh terhadap proses pengembangan sektor pertanian. Akibatnya terjadinya proses alih fungsi lahan pertanian menjadi lahan tapak industri. Ironisnya, lahan pertanian yang dikonversikan menjadi lahan tapak industri ini bukan lahan yang bersifat marjinal atau tidak subur, tetapi justru lahan yang beririgasi teknis. Akibat ke depan sangat memprihatikan, karena kemampuan Indonesia untuk mempertahankan swasembada beras akan menjadi sangat lemah. Fakta telah membuktikan bahwa sejak tahun 1990-an, pemerintah terpaksa mengimpor beras untuk memenuhi kebutuhan pangan domestik.

Pada dasarnya, pembangunan kawasan perkotaan merupakan bagian dari geo-politik kota. Menurut Evers (1992:25), struktur sosial dan ekonomi kota di Indonesia cenderung ditentukan oleh pengaruh besar administrasi daerah dan kaitan-kaitan komersialisasi sistem kapitalis dunia. Persoalan inilah yang memicu terjadinya tarik-menarik kepentingan terhadap sebuah "ruang", terutama antara kepentingan kapitalis dunia dengan kepentingan nasional. Singkat kata, lahan atau tanah merupakan sebuah "ruang" yang diperebutkan. Proses pembangunan yang masif pada akhirnya melahirkan ekses yang berupa sejumlah alih fungsi lahan persawahan.

Perkembangan wilayah di daerah perkotaan menempati posisi yang dominan dalam kajian keruangan, mengingat wilayah perkotaan cenderung lebih dinamis dan mempunyai kompleksitas yang sangat tinggi dibandingkan dengan daerah perdesaan.

Menurut Bhatta (2010), yang mengutip hasil penelitian Harvey dan Clark (1965), perkembangan kota dalam konteks keruangan (fisik) dapat dibedakan menjadi tiga model pertumbuhan kota yang meliputi: (1) Ribbon Development, yakni pertumbuhan fisik kota yang mengikuti jalurjalur transportasi; (2) Concentric Development, yakni pertumbuhan fisik kota yang menyebar secara merata pada semua sisi kota; (3) LeapFrog Development, yakni pertumbuhan kota yang menyebar secara sporadis di semua daerah pinggiran kota. Model ini sering juga disebut sebagai pembangunan "lompat katak."
Berdasarkan teori-teori di atas tampak bahwa perkembangan wilayah perkotaan seakan secara sistematis mendesak keberadaan wilayah pinggiran maupun perdesaan. Tidak dapat dipungkiri bahwa sebagian besar masyarakat mempunyai pemahaman bahwa perkembangan tampilan fisik kota merupakan simbol bagi sebuah kemajuan. Hal inilah yang kemudian semakin mempertinggi intensitas alih fungsi lahan dalam bentuk ekspansi wilayah kota terhadap wilayah desa.

Perkembangan suatu wilayah tidak terlepas dari pertumbuhan penduduk dan segala aktivitasnya untuk menopang hidup dan kehidupannya yang secara langsung maupun tidak langsung mempertinggi permintaan tanah. Faktor yang paling dominan yang berpengaruh terhadap struktur penggunaan tanah adalah kebutuhan permukiman bagi penduduk. Namun demikian realitas menunjukkan bahwa di banyak wilayah perkembangan permukiman tersebut umumnya menjadi tidak terkendali (unmanaged growth). Realitas ini adalah sebuah konsekuensi logis bagi daerah-daerah yang perkembangan wilayahnya relatif cepat.

\section{Alih Fungsi Lahan di Kota Bandung}

Sebagai ibukota Provinsi Jawa Barat, Kota Bandung memiliki visi sebagai kota yang bermartabat (bersih, makmur, taat dan bersahabat). Salah satu misi Kota Bandung adalah meningkatkan penataan kota, yang mencakup pemeliharaan serta peningkatan prasarana dan sarana kota agar sesuai dengan dinamika peningkatan kegiatan kota dengan tetap memerhatikan tata ruang dan daya dukung lingkungan perkotaan.

Tantangan yang dihadapi saat ini adalah semakin besarnya laju pertumbuhan penduduk membuat kebutuhan terhadap lahan semakin meningkat dan berimplikasi pada melambungnya harga lahan di Kota Bandung. Hal tersebut menyebabkan lahan yang tadinya diperuntukkan sebagai kawasan lindung di dalam Rencana Tata Ruang Wilayah (RTRW) terpaksa menjadi kawasan budidaya. Pemerintah Kota Bandung dituntut mencari solusi yang tepat sebelum lahan tersebut dibebaskan dan diklaim sebagai Ruang Terbuka Hijau (RTH).

Alih fungsi pemanfaatan ruang dan lingkungan hidup di Kota Bandung merupakan penyebab sulitnya untuk merealisasikan pemenuhan luasan RTH dari proporsi yang telah ditentukan. Luasan RTH yang ada saat ini, belum sesuai dengan target yang ditetapkan dalam RTRW Kota Bandung, yaitu sebesar $10 \%$ dari luas wilayah Kota Bandung dan juga belum dapat memenuhi ketentuan Undang- 
Undang Nomor 26 Tahun 2007 tentang Penataan Ruang yang menetapkan bahwa luas ideal Ruang Terbuka Hijau Kawasan Perkotaan (RTHKP) minimal $30 \%$ yang terdiri dari $20 \%$ ruang terbuka hijau publik dan $10 \%$ terdiri dari ruang terbuka privat dari luas kawasan.

Pemerintah Kota Bandung memang secara bertahap mengembangkan luasan RTH. Hal ini terlihat dari persentase total luasan RTH pada tahun 2007 yang seluas $8,76 \%$ menjadi $11,43 \%$ pada tahun 2011. Pertambahan luasan ini menunjukkan adanya komitmen mendukung pelestarian lingkungan hidup. Namun, untuk memenuhi target $20 \%$ luasan RTH publik, terlihat berat karena harus menambah alokasi RTH sebanyak 18,6\%. Hal ini berarti bahwa sumbangan terbesar RTH di Kota Bandung adalah dari RTH privat.

Susahnya mencari ruang terbuka di Kota Bandung terlihat di sepanjang sempadan Sungai Cikapundung misalnya, yang saat ini didominasi oleh kawasan perdagangan dan perumahan. Hal ini jelas bertentangan dengan ketentuan perundangundangan yang menyatakan bahwa sepanjang sempadan sungai masuk ke dalam RTH taman yang harus dikembangkan secara bertahap. Artinya lokasi tersebut tidak diperuntukkan untuk kawasan budidaya dan menjadi tugas Pemerintah untuk memulihkan atau mengembalikan fungsi kawasan tersebut menjadi kawasan lindung.

Berbagai perubahan di atas timbul sebagai akibat perkembangan yang pesat dari kegiatan industri, perdagangan, dan jasa. Semua ini telah menjadikan Kota Bandung sedemikian menarik, tidak hanya bagi penduduk yang berasal dari Jawa Barat sendiri tetapi dari provinsi-provinsi lain di Indonesia.

Sejalan dengan pertumbuhan penduduk ini, sektor ekonomi Kota Bandung bergerak cepat sehingga sering disebut sebagai kota metropolitan ketiga di Indonesia setelah Jakarta dan Surabaya. Karakter metropolitan, yang diindikasikan secara ekonomi melalui tumbuhnya mega mal, supermarket dan hypermarket.

Perkembangan yang sangat terlihat adalah industri fashion yang terlihat dari menjamurnya FO (factory outlet) dan Distro (distribution store) sebagai agen distribusi produk tekstil. Industri kreatif fashion sudah menjadi icon Kota Bandung. Kekuatan utama industri kreatif adalah desain, keragaman bahan baku, kekhususan merek, dan keunikan produk.

Berkaitan dengan fenomena sosial-ekonomi di atas, terdapat 2 konsekuensi langsung yang dihadapi Kota Bandung yaitu laju perkembangan atau pertumbuhan yang tinggi dan cenderung tidak terkendali. Kedua, semakin meningkatnya pemanfaatan sumber daya alam yang ada, terutama sumber daya lahan dan sumber daya air yang pada akhirnya dapat merusak daya dukung lingkungan. Kedua konsekuensi ini bekerja secara timbal balik, yang secara kumulatifmenghasilkan bentuk tekanan internal bagi Kota Bandung, yaitu kemacetan lalu lintas, perkembangan tata guna lahan yang tidak tertib dan teratur, serta daya dukung lingkungan yang semakin menurun.

Dari sisi kemacetan lalu lintas yang terjadi di Kota Bandung setidaknya dipicu oleh tidak sebandingnya ketersediaan lahan dengan kebutuhan transportasi. Kemacetan lalu lintas ini seringkali direspon oleh mekanisme pasar (ekonomi) lahan, dalam bentuk semakin dekat pusat kota maka semakin mahal harga lahannya. Bagi penduduk yang memiliki keterbatasan ekonomi, tentunya tidak ada pilihan selain mencari lahan baru di luar kota atau memilih lahan di dalam kota dengan kompensasi tertentu, seperti kualitas lingkungan yang berbeda, at au luasan lahan yang tidak sepadan. Oleh karena itu, kawasan permukiman kumuh semakin bertambah di wilayah dalam perkotaan.

Berdasarkan data demografi BKKN Provinsi Jawa Barat (2012), Kota Bandung memiliki 665.252 penduduk usia remaja (10-24 tahun) pada tahun 2013. Jumlah ini setara dengan 28,55 persen dari total populasi. Sementara proporsi remaja terbanyak adalah pada kelompok umur 2024 tahun berjumlah sekitar 35,5 persen dari total populasi remaja. Data ini membuktikan bahwa Kota Bandung didominasi oleh remaja dan usia produktif yang masih membutuhkan lahan untuk perumahan di kemudian hari nanti. Angka ini ditambah lagi dengan bertambahnya para pelajar atau mahasiswa yang berasal dari luar kota yang mau tidak mau juga harus disediakan lahan untuk tempat tinggal sementara.

Akibat adanya desakan dari internal dan juga eksternal, maka persoalan Kota Bandung berikutnya adalah susahnya mencari lahan, bahkan untuk lahan yang sifatnya wajib dimiliki oleh pemerintah kota sekalipun. Sampai saat ini, Kota Bandung tidak memiliki lahan untuk Tempat Pembuangan Sampah (TPS) dan tempat parkir kendaraan bermotor yang memadai. Dikarenakan semua lahan yang ada, hampir semua telah dipergunakan.

Akibat dari tekanan urbanisasi dan perubahan demografi ini maka permasalahan berikutnya adalah perkembangan guna lahan yang acak. Penyebaran hunian yang umumnya berbentuk acak dan tersebar menyebabkan mahalnya biaya pembangunan infrastruktur. Dengan adanya keterbatasan fiskal pemerintah kota 
mengakibatkan adanya kesenjangan pelayanan infrastruktur sebagai kebutuhan dasar. Selain itu, karakter sosial masyarakat Parahyangan yang "ngariung" atau senang berkumpul, mendistorsi pasar lahan sehingga mekanisme pasar lahan tidak bekerja secara penuh. Sebagai akibat tuntutan atas pemenuhan kebutuhan dasar dan tuntutan pola hidup metropolis di atas, perkembangan guna lahan yang menyebar ini cenderung akan membentuk extended metropolitan region.

Konsekuensi berikutnya adalah daya dukung lingkungan yang menurun. Hal ini disebabkan pemanfaatan sumber daya yang ekstensif tanpa didukung oleh strategi pengelolaan pertumbuhan wilayah yang terintegrasi ant arsektor pembangunan. Perubahan iklim mikro, pencemaran air permukaan dan polusi udara, serta penurunan muka air tanah dalam, merupakan indikasi kuat atas penurunan daya dukung lingkungan ini. Untuk mengatasi permasalahan-permasalahan di atas, maka tidak ada cara selain konsisten dalam mengembangkan perencanaan tata ruang metropolitan Bandung yang menerapkan prinsip-prinsip penataan ruang berkelanjutan.

Pertumbuhan penduduk wilayah metropolitan Bandung rata-rata 2,7 persen per tahun dengan tingkat pertumbuhan tertinggi berada di wilayah Kota Bandung dan sekitarnya yakni sekitar 3,7 persen. Dengan asumsi bahwa sampai dengan tahun 2025 belum ada upaya pengendalian mobilitas penduduk secara efektif maka laju pertumbuhan penduduk akan tetap tumbuh rata-rata 2,86 persen maka akan mencapai jumlah 14,67 juta jiwa pada tahun 2025. Dari perkiraan jumlah penduduk tersebut maka 70 persen atau sekitar 10 juta merupakan penduduk perkotaan yang bermukim di sekitar wilayah kota.

Bertitik tolak dari perkiraan laju pertumbuhan penduduk yang relatif tinggi tersebut dan distribusi penyebarannya yang tidak merata, maka perlu upaya penanganan yang lebih serius terhadap upaya mengendalikan laju pertumbuhan penduduk serta penyebarannya khususnya di Kota Bandung. Upaya secara serius tersebut perlu dilakukan baik melalui mekanisme administratif maupun mekanisme nonadministratif.

Dari evaluasi terhadap pengembangan kawasan menunjukkan bahwa pembent ukan kota-kota satelit di sekitar Kota Bandung tidak berjalan efektif karena masih kuatnya peranan Kota Bandung. Hal ini dikarenakan belum terwujudnya pengembangan infrastruktur dan fasilitas utama ke kota-kota di sekitar wilayah inti, belum efektifnya mekanisme pengendalian pembangunan, dan terbatasnya kemampuan pembiayaan serta belum optimalnya koordinasi. Kondisi ini mengakibatkan terjadinya pembangunan yang tetap terkonsentrasi di sekitar wilayah inti Kota Bandung, pengembangan permukiman mengikuti pola jaringan jalan utama (ribbon development) serta pengembangan permukiman di sekitar pinggiran Kota Bandung dan Cimahi bersifat tidak terintegrasi (sprawl development) yang mengakibatkan tidak efisien penyediaan infrastruktur dan fasilitas serta semakin mendorong terjadinya penurunan daya dukung lingkungan perkotaan.

Saat ini, lahan pertanian yang masih tersisa di Kota Bandung jumlahnya sangat sedikit. Menurut Yatty Mulyati Feliana Direja dari Bappeda Kota Bandung, lahan pertanian tersisa hanya beberapa hektar saja yang terletak di wilayah Cibiru atau wilayah timur Kota Bandung (wawancara 22 Juli 2014). Guna mengantisipasi kekurangan lahan pertanian tersebut, Dinas Pertanian Kota Bandung mulai menerapkan konsep urban farming. Dengan keterbatasan lahan pertanian maka pola tanam menggunakan media yang tersedia di perkotaan seperti penanaman dalam pot dan lain-lain.

\section{Alih Fungsi Lahan di Kota Yogyakarta}

Berdasarkan penelitian Susi Wuri Ani (2006), pada tahun 2006 di Provinsi DIY masih terdapat lahan sawah seluas 57.661 hektare yang kemudian menyusut menjadi 56.538 hektare pada 2010 . Artinya, hanya dalam waktu empat tahun, 1.123 hektare lahan pertanian di DIY telah beralih fungsi.

Jika diperhatikan penyebabnya adalah karena semakin pesatnya industri pariwisata, perdagangan, dan jasa. Bahkan khusus lahan pertanian di Kota Yogyakarta, hanya tersisa sedikit di wilayah Nitikan (Suyono, Kepala Dinas Pertanian Kota Yogyakarta, wawancara, 5 November 2014).

Dalam beberapa tahun terakhir, laju pertumbuhan Produk Domestik Regional Bruto (PDRB) dari sektor pertanian di DIY memang mengalami pertumbuhan negatif. Jika tahun 2010, sektor pertanian menyumbang PDRB sebesar Rp 3,63 triliun, pada tahun 2011 angkanya turun 2,12 persen menjadi Rp 3,55 triliun. Pelan tapi pasti, sektor pertanian di Yogyakarta pelan-pelan mulai ditinggalkan oleh penduduknya.

Minimnya sumbangsih sektor pertanian terhadap perekonomian DIY tidak terlepas dari kultur pertanian masyarakatnya. Kebanyakan pertanian di Provinsi Yogyakarta adalah pertanian dalam skala kecil dengan luas lahan sekitar 0,3 hektar per kepala keluarga. Kebanyakan mereka adalah petani utun yaitu petani yang juga merangkap sebagai tukang (kayu atau batu), peternak, bahkan menarik becak. Lebih dari 80 persen petani di DIY adalah petani 
gurem. Rata-rata latar belakang pendidikan sebagian besar petani (70,64 persen) hanya setara atau tidak lulus sekolah dasar. Selain itu, lebih dari 40 persen anggota rumah tangga pertanian hanya berstatus buruh tani. Hampir separuh (46 persen) dari buruh tani tersebut juga sudah berusia lanjut yaitu di atas 55 tahun (Ani, 2006).

Berdasarkan data-data di atas, tidaklah mengherankan jika tekanan ekonomi untuk menghidupi keluarga membuat banyak rumah tangga pertanian yang masih memiliki lahan sendiri begitu mudahnya untuk menjual lahan persawahannya. Tren semacam ini akan terus terjadi, meskipun Provinsi DIY telah membuat Peraturan Daerah Nomor 10 Tahun 2011 tentang Perlindungan Lahan Pangan Berkelanjut an (PLPB) sebagai implementasi Undang-Undang Nomor 41 Tahun 2009 tentang PLPB.

Keadaan sektor pertanian yang mengenaskan lebih jelas terlihat di Kota Yogyakarta. Luas wilayah Kota Yogyakarta adalah $32,5 \mathrm{~km}^{2}$ atau cuma 1,02 persen dari total luas wilayah provinsi DIY $\left(3.186 \mathrm{~km}^{2}\right)$. Berdasarkan data administratif dari buku Kota Yogyakarta dalam Angka Tahun 2008, jumlah penduduk Kota Yogyakarta hanya sebanyak 456.918 orang. Namun jika diperluas definisi Kota Yogyakarta tidak hanya wilayah administratif saja, maka penduduk wilayah perkotaan Yogyakarta pada tahun 2008 saja sudah mencapai 1.127.305 jiwa. Jumlah tersebut meliputi 456.918 jiwa penduduk Kota Yogyakarta, 254.361 jiwa penduduk di daerah perkotaan di Kabupaten Bantul dan untuk perkotaan di Kabupaten Sleman mencapai 416.026 jiwa. Dengan total luas wilayah mencapai $279,2 \mathrm{~km}^{2}$, maka kepadatan penduduk di wilayah Perkotaan Yogyakarta mencapai 4.036 jiwa $/ \mathrm{km}^{2}$.

Bila dirinci menurut wilayah, maka Kota Yogyakarta memiliki kepadatan penduduk tertinggi yaitu mencapai $14.056 / \mathrm{km}^{2}$. Pada wilayah sub-urban, kepadatan penduduk Kabupaten Sleman mencapai 2.622 jiwa $/ \mathrm{km}^{2}$, sedangkan kepadatan penduduk di Kabupaten Bantul mencapai 2.890 jiwa $/ \mathrm{km}^{2}$.

Keunikan karakteristik DIY menyebabkan disandangnya berbagai atribut seperti Kota Pelajar, Kota Budaya, Kota Pensiunan, dan lain-lain. Atribut ini akhirnya berimplikasi terhadap peningkatan penduduk yang masuk ke wilayah DIY sehingga berdampak terhadap peningkatan permintaan lahan untuk berbagai kepentingan nonpertanian seperti rumah tinggal, investasi, bisnis pergudangan, sentra industri, maupun pariwisata.

Terbatasnya lahan nonpertanian yang tersedia di wilayah Kota Yogyakarta untuk memenuhi kebutuhan lahan untuk pembangunan tersebut berdampak terhadap digunakannya lahan-lahan pertanian produktifuntuk kepentingan nonpertanian di pinggiran Kota Yogyakarta. Sebagai implikasi dari fenomena ini adalah menjamurnya perubahan lahan pertanian produktif menjadi bangunanbangunan untuk berbagai jenis kepentingan, terutama di pinggiran Kota Yogyakarta.

Perkembangan pemanfaatan ruang di Kota Yogyakarta ditandai dengan berkembanganya infrastruktur transportasi (berupa jaringan jalan dan moda transportasi), peningkatan pemanfaatan ruang dari satu jenis (pertanian) menjadi beberapa jenis pemanfaaatan (permukiman, perdagangan, perkantoran, dan jasa) mengakibatkan peningkatan harga. Proses perubahan penggunaan lahan ini juga diikuti dengan perubahan pemilikan lahan yang awalnya dimiliki oleh masyarakat menjadi milik para pemodal. Para investor, pengembang perumahan, maupun pendatang yang memiliki modal memberikan penawaran yang menarik bagi masyarakat pemilik lahan sehingga mau menjual lahannya. Tekanan perkembangan perkotaan terhadap kegiatan pertanian yang kurang produktif juga menjadi alasan mengapa masyarakat mau menjual lahan.

Persaingan penggunaaan lahan di berbagai sektor menyebabkan terjadinya alokasi lahan ke arah penggunaan lahan yang memiliki rent paling tinggi. Land rent merupakan surplus pendapatan di atas pengeluaran biaya untuk lahan yang memungkinkan faktor produksi dapat dimanfaatkan dalam proses produksi. Besarnya sewa tanah ditentukan oleh kesuburan dan lokasi tanah.

Secara umum, terdapat hubungan antara land rent dengan penggunaan lahan. Urut an penggunaan lahan yang memberikan land rent tertinggi sampai terendah adalah lahan untuk perdagangan dan industri atau komersial, diikuti penggunaan lahan untuk permukiman, pertanian, hutan, padang rumput dan rawa.

Kenaikan jumlah penduduk yang ada di Yogyakarta sebagian besar dikarenakan migrasi penduduk, meskipun juga ada karena fertilitasmortalitas. Sumbangan angka kenaikan penduduk dari fertilitas-mortalitas tidak terlalu signifikan bila dibandingkan dengan angka migrasi karena sebagian besar imigran yang datang ke Yogyakarta umumnya berpendidikan tinggi sehingga mereka mempunyai kesadaran tinggi tentang keluarga berencana (KB).

Kota Yogyakarta juga menjadi pusat perdagangan dan jasa, khususnya pariwisata. Pertumbuhan perekonomian yang pesat merupakan faktor penarik bagi imigran untuk melakukan 
Tabel 1. Jumlah Penduduk, Laju Pertumbuhan dan Kepadatan Penduduk di Provinsi DIY Tahun 2011

\begin{tabular}{llrrr}
\hline No. & Kabupaten/Kota & $\begin{array}{c}\text { Jumlah Laju } \\
\text { (jiwa) }\end{array}$ & Pertumbuhan (\%) & $\begin{array}{r}\text { Kepadatan Penduduk } \\
\left(\mathbf{j i w a} / \mathbf{m}^{2}\right)\end{array}$ \\
\hline 1. & Kulon Progo & 390.446 & 0,34 & 665,58 \\
2. & Bantul & 921.263 & 1,07 & $1.817,63$ \\
3. & Gunung Kidul & 677.998 & 0,39 & 456,45 \\
4. & Sleman & 1.107 .304 & 1,30 & $1.926,35$ \\
5. & Yogyakarta & 390.553 & 0,50 & $12.017,02$ \\
\hline Total & & 3.487 .325 & 0,86 & $1.094,65$ \\
\hline
\end{tabular}

Sumber: BPS Provinsi DIY, 2012

perpindahan penduduk dari daerah asal ke Yogyakarta.

Dalam mengatasi tingginya alih fungsi lahan pertanian di Kota Yogyakarta, perlu adanya pengendalian yang ketat. Pengendalian alih fungsi lahan dapat dilakukan dengan mengendalikan faktorfaktor yang secara signifikan memengaruhi alih fungsi lahan. Dari faktor internal sektor pertanian dapat dilakukan upaya untuk meningkatkan nilai produk pertanian agar petani pemilik lahan tetap tertarik untuk berusaha tani karena hasil yang diperoleh dapat mencukupi kebutuhan hidupnya, yaitu dengan intensifikasi pertanian untuk meningkatkan produksi pertanian dan menetapkan harga jual minimum untuk hasil produksi pertanian.

Faktor lainnya yang dapat menjadi instrumen bagi pengendalian alih fungsi lahan adalah penertiban kegiatan pembangunan melalui tata ruang wilayah, pengendalian pertumbuhan jumlah penduduk, serta pemberian insentif bagi para petani agar bersedia mempertahankan lahan pertaniannya dalam menghadapi harga lahan pertanian yang terus meningkat. Insentif tersebut lebih diarahkan pada pembentukan usaha tani yang mandiri agar petani dapat mengembangkan usahanya sehingga dapat menjadi sumber penghasilan untuk menunjang kebutuhan hidupnya. Upaya pengendalian tersebut tentu saja memerlukan peran aktif dari berbagai pihak terkait.

Selain itu, alih fungsi lahan juga dikarenakan persebaran penduduk antara daerah perkotaan dan predesaan di Kota Yogyakarta yang tidak merata. Jumlah penduduk yang bermukim di daerah perkotaan meningkat dengan cepat dibandingkan dengan penduduk yang bermukim di pedesaan. Kondisi tersebut menyebabkan permintaan kebutuhan lahan dengan ketersediaan lahan tidak seimbang. Selanjutnya kecenderungan meningkatnya kebut uhan lahan yang terkonsentrasi di wilayah tertentu ini mengakibatkan terlampauinya batas daya dukung lahan. Perkembangan tersebut memaksa Kota Yogyakarta melakukan perluasan kotanya ke daerah pinggiran. Salah satu wilayah pinggiran yang mengalami dampak yang paling besar adalah Kecamatan Umbulharjo. Kecamatan Umbulharjo yang semula merupakan wilayah pertanian mulai berubah fungsi menjadi wilayah nonpertanian khususnya permukiman.

Penyusutan dan alih fungsi lahan pertanian (baik untuk bangunan perumahan, perkantoran, industri, maupun pertokoan), maka produksi pertanian dari tahun ke tahun tidak pernah optimal. Hal ini mengakibatkan Kota Yogyakarta diduga akan mengalami krisis pangan di masa mendatang.

Kondisi daya dukung lingkungan alam Kota Yogyakarta juga dapat dilihat dari RTHnya. Tingginya tingkat pertambahan penduduk terutama akibat urbanisasi merupakan salah satu permasalahan kota-kota di Indonesia. Jumlah penduduk perkotaan yang tinggi yang terus meningkat dari waktu ke waktu memberikan dampak tingginya tekanan terhadap pemanfaatan ruang kota, terutama berkurangnya ruang-ruang terbuka (open space), yang berupa RTH maupun ruang lainnya sebagai ruang terbuka publik yang berpotensi menjadi ruang permukiman atau ruang budidaya. Oleh sebab itu Pemerintah Kota Yogyakarta mempunyai komitmen yang tinggi dengan permasalahan RTH. Untuk itu programprogram yang menunjang $\mathrm{RTH}$, baik yang bersifat publik maupun privat mendapat prioritas yang tinggi dalam pembangunan wilayahnya.

Dalam rangka pengaturan RTH maka Pemerintah Kota Yogyakarta mengeluarkan regulasi dalam bentuk peraturan walikota yakni Peraturan Walikota Yogyakarta Nomor 5 Tahun 2007 tentang Pengelolaan Ruang Terbuka Hijau dan Peraturan Walikota Yogyakarta Nomor 6 Tahun 2010 tentang Penyediaan Ruang Terbuka Hijau Privat. Hal ini menunjukkan komitmen yang tinggi bagi pemerintah kota terhadap RTH tersebut. 
Berdasarkan data Badan Lingkungan Hidup Kota Yogyakarta tahun 2010, RTH publik yang dibangun pemerintah masih kurang dari 20 persen atau hanya 17,17 persen $(557,90$ hektare) dari luas wilayah Kota Yogyakarta. Kurangnya pembangunan RTH publik di wilayah kota diakibatkan karena keterbatasan lahan yang bisa digarap untuk pembangunan RTH tersebut. Maraknya pembangunan beragam proyek yang melanggar aturan lingkungan menjadi penyebab semakin kritisnya ketersediaan RTH di Kota Yogyakarta. Permintaan akan pemanfaatan lahan kota yang terus tumbuh dan bersifat akseleratif untuk pembangunan berbagai fasilitas perkotaan, termasuk kemajuan teknologi, industri dan transportasi, selain sering mengubah konfigurasi alami lahan/bentang alam perkotaan juga menyita lahan-lahan tersebut dan berbagai bentukan ruang terbuka lainnya. Pembangunan mal, hotel dan beragam fasilitas lainnya hampir tidak satupun yang memenuhi ketentuan untuk berpihak kepada menjaga lingkungan.

\section{Penutup}

\section{Simpulan}

Berdasarkan penelitian di Kota Bandung dan Kota Yogyakarta, penyebab terjadinya alih fungsi lahan dapat diklasifikasikan sebagai berikut:

Faktor pertambahan penduduk. Dengan menyandang masing-masing sebagai ibukota provinsi, Kota Bandung dan Kota Yogyakarta merupakan di antara kota-kota besar di Indonesia yang haus akan permintaan lahan permukiman sekaligus jasa, yang semakin meningkat dari tahun ke tahun.

Faktor ekonomi perdesaan di sekitar Kota Bandung dan Kota Yogyakarta yang masih dirundung problem akut kemiskinan. Masyarakat perdesaan yang tidak mampu memenuhi kebutuhan hidupnya melalui kegiat an pertanian, akan berusaha mencari bentuk usaha lain yang dapat meningkatkan kesejahteraan mereka dengan segera, yaitu dengan menjual tanah yang dimilikinya dengan anggapan akan mendapatkan keuntungan yang lebih tinggi dari penjualan lahan pertanian untuk kegiatan industri dibandingkan harga jual untuk kepentingan persawahan. Pada saat yang sama masyarakat kota yang tidak atau belum memiliki lahan untuk perumahan, berusaha akan mencari lahan di pinggiran kota yang umumnya lebih terjangkau harganya. Akibatnya, proses ekspansi wilayah kota pada akhirnya mencaplok wilayah pinggiran kota, dan seterusnya.

Adanya penanaman modal pihak swasta yang masif dengan membeli lahan-lahan produktif milik warga. Investasi pada modal ini umumnya membutuhkan lahan seperti pembangunan ruko, mal, pusat perbelanjaan dan lain. Hampir sama dengan laju kebutuhan perumahan, pertumbuhan pusat-pusat ekonomi juga melaju seiring perkembangan wilayah perkotaan yang mulai merambah pinggiran kota.

Ketidak-konsistenan pemerintah daerah dalam mempertahankan desain wilayah sebagaimana yang telah ditetapkan dalam Rencana Tata Ruang Wilayah (RTRW). Umumnya pemerintah daerah tergoda untuk mengalokasikan lahan permukiman atau perumahan real estate karena alasan jangka pendek.

Baik di Kota Bandung dan Kota Yogyakarta, keduanya tengah mengalami perubahan yang tidak hanya secara spasial kaitannya dengan perubahan penggunaan lahan, namun juga perubahan secara sosial, ekonomi dan budaya. Perubahan pemanfaatan lahan yang pasti terjadi adalah perubahan penggunaan lahan dari pertanian ke nonpertanian. Lahan pertanian baik yang berupa sawah, tegalan, ataupun ladang, berubah menjadi lahan terbangun baik itu berupa komplek perumahan, permukiman tunggal, maupun komplek perdagangan dan jasa. Perubahan orientasi pemanfaatan lahan ini akan berpengaruh terhadap produksi dan hasil penggunaan lahan yang erat kaitannya dengan kondisi sosial ekonomi pemilik lahan maupun penjual lahan. Kondisi ini juga mengakibatkan perubahan budaya masyarakat agraris yang telah berlangsung sejak lama menuju ke budaya nonagraris.

Beberapa kebijakan sebenarnya sudah dibuat untuk mengantisipasi beralihnya lahan pertanian ke nonpertanian seperti melalui penetapan Peraturan Daerah. Namun kebijakan ini terbukti sulit dilaksanakan karena pemerintah daerah sendiri tidak mampu mengendalikan laju alih fungsi lahan tersebut. Artinya, otoritas pemerintahan masih belum memiliki komitmen kuat untuk mengimplementasikannya.

\section{Saran}

Perlu adanya komitmen bersama dari seluruh stakeholder di Kota Bandung dan Kota Yogyakarta untuk merespon perkembangan terbaru tata ruang di kedua kota tersebut agar dapat menahan laju alih fungsi lahan serta mengembalikan fungsi Ruang Terbuka Hijau (RTH) yang selama ini terabaikan akibat tuntutan perkembangan ekonomi di kedua kota tersebut.

Masih diperlukan upaya legislasi dan komitmen untuk menegakkan aturan agar pembangunan di kedua kota tersebut terarah dalam mengembangkan 
program-program yang mendukung arah visi dan misi terwujudnya kota layak huni bagi penduduknya maupun pendatang dengan menerapkan prinsipprinsip penataan ruang berkelanjutan.

Perlu upaya yang kuat dari pemerintah di kedua kota tersebut untuk mensinergikan kebijakan dan program sesuai dengan visi dan misi dengan pengembangan kebijakan berupa penataan kota yang lebih baik. Ke depan, dimungkinkan pengembangan rumah susun di kedua kota tersebut sebagai alternatif penyediaan pemukiman yang sehat dan nyaman di tengah desakan alih fungsi lahan.

\section{DAFTAR PUSTAKA}

\section{Buku}

Ani, Susi Wuri. 2006. Kajian Alih Fungsi Lahan Pertanian terhadap Ketersediaan Beras di Daerah Istimewa Yogyakarta. Tesis. Pascasarjana Ekonomi Pertanian Universitas Gajah Mada. Yogyakarta.

Ashari. 2001. Hubungan Pertumbuhan Penduduk dan Ekonomi dengan alih Fungsi Lahan Sawah ke NonSawah di Pulau Jawa. Tesis. Program Studi Ekonomi Pertanian, Program Pascasarjanan UGM. Yogyakarta.

Barlowe, R. 1978. Land Resources Economic, New Jersey: Prentice-Hall Inc.

Basundoro, Purnawan. 2012. Pengantar Sejarah Kota. Yogyakarta: Ombak.

Colombijn, Freek. 2010. Under Construction: The Politics of Urban Space and Housing During the Decolonization of Indonesia, 1930-1960. Leiden: KITLV Press.

Fahmuddin, Agus. 2004. Konversi dan Hilangnya Multifungsi Lahan Sawah. Jakarta: Badan Penelitian dan Pengembangan Pertanian.

Ilham, Nya. 2003. Perkembangan dan Faktor-Faktor yang Mempengaruhi Konversi Lahan Sawah serta Dampak Ekonominya. Bogor: IPB Press.

Irianto, Selamat. 2008. Analisis Kebijakan Program Pembangunan Prasarana Kota Terpadu (P3KT) Kota Liwa Kabupaten Lampung Barat dan Arah Kebijakan Pembangunan Kota Liwa Pada Era Otonomi Daerah (Studi Kasus P3KT: Komponen Air Bersih). Tesis. Perpustakaan Universitas Indonesia.

Kivell, P. 1993. Land and the City: Patterns and Processes of Urban Change. London: Rautledge.
Masahisa Fujita. 1989. Urban Economic Theory: Land Use and City Size, New York: Cambridge University Press.

Pearce, D.W. dan R.K. Turner. 1990. Economics of Natural Resources Environment. London: Harvester Wheatsheaf.

Setyobudi, Imam. 2001. Menari di Antara Sawah dan Kota: Ambiguitas Diri, Petani-Petani Terakhir di Yogyakarta, Magelang: Yayasan Indonesiatera.

Wibowo, S.C. 1996. Analisis Pola Konversi Sawah Serta Dampaknya Terhadap Produksi Beras: Studi Kasus di Jawa Timur. Jurusan Tanah, Fakultas Pertanian, Institut Pertanian Bogor. Bogor.

Yunus, H.S. 2001. Perubahan Pemanfaatan Lahan di Daerah Pinggiran Kota: Kasus Pinggiran Kota Yogyakarta. Disertasi. Program PascasarjanaUGM, Yogyakarta.

Yunus. H,S. 2005. Manajemen Kota: Perspektif Spasial. Yogyakarta: Pustaka Pelajar.

\section{Jurnal}

Afandi H.M., Indayati dan Suman A. 2008. "Analisis Faktor Keputusan Petani Menjual Lahannya." Agritek Volume 17 Nomor 3 Tahun 2008 Halaman 416-423.

Brahmantyo, Thedorus, Iwan Kustiwan. 2013. "Evaluasi Penyediaan Ruang Terbuka Hijau sebagai Infrastruktur Hijau di Kota Bogor dan Cirebon." Perencanaan Wilayah dan Kota Volume 2 Nomor 1, April 2013.

Irawan, B. 2005. "Konversi Lahan Sawah: Potensi Dampak, Pola Pemanfaatannya, dan Faktor Determinan." Forum Penelitian Agro Ekonomi. Volume 23 Nomor 1 Juni 2005. Pusat Analisis Sosial Ekonomi dan Kebijakan Pertanian. Bogor.

Irawan, B., S. Friyatno. 2002. "Dampak Konversi Lahan Sawah di Jawa Terhadap terhadap Produksi Beras dan Kebijakan Pengendaliannya." Soca (SocioEconomic of Agriculture and Agribusiness). Volume 2 Nomor 2 Tahun 2002. Pusat Penelitian dan Pengembangan Sosial Ekonomi Pertanian, Badan Penelitian dan Pengembangan Pertanian, Bogor.

Kustiawan, I. 1997. "Konversi Lahan Pertanian di Pantai Utara Jawa." Prisma. Nomor 1 Tahun 1997. Pustaka LP3ES, Jakarta.

Lutfi Nasution. 1991. "Beberapa Masalah Pertanahan Nasional dan Alternatif Kebijakan untuk Menanggulanginya." Analisis. Nomor 2 Tahun 1991.

Pond, Bruce, Maurice Yeates, 1993. "Rural/Urban Land Conversion I: Estimating the Direct and Indirect Impact." Urban Geography. Nomor 14 Tahun 1993. 
Setiawan, B., A. Purwanto, "Proses Konversi Lahan Pertanian di Pinggiran Kota: Studi Kasus di Daerah Pinggiran Kota Yogyakarta." Manusia dan Lingkungan. Nomor 3 Tahun 1994.

Sumaryoto, Iqbal, M., 2007. "Strategi Pengendalian Alih Fungsi Lahan Pertanian Bertumpu Pada Partisipasi Masyarakat." Warta Penelitian dan Pengembangan Pertanian. Volume 5 Nomor 2 halaman 167-182. Pusat Analisis Sosial Ekonomi dan Kebijakan Pertanian, Bogor.

W. Lockeretz. 1989. "Secondary Effects on Midwestern Agriculture of Metropolitan Development and Decreases in Farmland." Land Economics. Volume 65 Nomor 3, Agustus 1989.

\section{Dokumen}

Badan Perencanaan Daerah Kota Bandung. 2004. Rencana Tata Ruang Wilayah Kota Bandung 2013. Bandung.

Badan Perencanaan Daerah Provinsi Jawa Barat. 2002. Analisis Volume Kecenderungan dan Karakteristik Migran Masukke Jawa Barat Tahun 2000. Bandung.

Badan Perencanaan Pembangunan Daerah dan Badan Pusat Statistik Jawa Barat. 2002. Analisis Volume Kecenderungan dan Karakteristik Migrasi Masuk ke Jawa Barat. Bandung.

Badan Pusat Statistik Kota Bandung. 2003. Bandung dalam Angka Tahun 2003. Bandung.

Badan Pusat Statistik. 1997. Perpindahan Penduduk dan Urbanisasi di Indonesia, Hasil Survey Penduduk Antar Sensus (SUPAS) 1995 Seri: S4. Jakarta.

Badan Pusat Statistik. 1999. Dinamika Petumbuhan Penduduk Tujuh Kota Besar di Indonesia: Bandung dan Sekitarnya. Jakarta.

Badan Pusat Statistik. 2001. Penduduk Jawa Barat: Hasil Sensus Penduduk Tahun 2000 Seri L 2.2. Bandung.

Badan Pusat Statistik. 2010. Propinsi Daerah Istimewa Yogyakarta dalam Angka. BPS Yogyakarta.

Bappeda Provinsi Jawa Barat. 2001. RTRWP Jawa Barat Tahun 2010. Bandung.

Bappenas dan PSE-KP. 2006. Penyusunan Strategi Pengendalian Alih Fungsi Lahan Pertanian. Kerjasama Direktorat Pangan dan Pertanian-Kantor Menteri Negara Perencanaan Nasional dengan Pusat Analisis Sosial Ekonomi dan Kebijakan Pertanian. Jakarta.

Dinas Tata Ruang dan Permukiman. 2004. Rencana Strategis Pengembangan Infrastruktur Metropolitan Bandung 2010. Bandung.

Dirjen PLA. 2005. Strategi dan Kebijakan Pengelolaan Lahan. Direktorat Jenderal Pengelolaan Lahan dan Air, Departemen Pertanian. Jakarta.
Winoto, J. 2005. 'Kebijakan Pengendalian Alih Fungsi Lahan Pertanian dan Implementasinya." Makalah Seminar Penanganan Konversi Lahan dan Pencapaian Lahan Pertanian Abadi. Kerjasama Kantor Kementerian Koordinator Bidang Perekonomian dengan Pusat Studi Pembangunan Pertanian dan Pedesaan IPB. Jakarta.

Witjaksono, R. 1996. "Alih Fungsi Lahan: Suatu Tinjauan Sosiologis, Prosiding," Lokakarya Persaingan dalam Pemanfaatan Sumberdaya Lahan dan Air: Dampaknya terhadap Keberlanjutan Swasembada Beras, 113-120. Kerjasama Pusat Penelitian Sosial Ekonomi Pertanian dengan Ford Fondation, Bogor.

World Bank, 1975, Land Reform Policy. World Bank, Washington, D.C.

\section{Peraturan Perundang-undangan}

Peraturan Pemerintah Nomor 30 Tahun 2012 tentang Pembiayaan Lahan Pertanian Pangan Berkelanjutan.

Undang-Undang Nomor 41 Tahun 2009 tentang Perlindungan Lahan Pertanian Pangan Berkelanjutan.

\section{Internet}

“28,55\% Penduduk Kota Bandung Berusia Remaja,” http:// jabar.bkkbn.go.id/ViewBerita.aspx?BeritaID=1301, diakses 15 November 2015.

Basundoro, Purnawan. 2013. "Perebutan Ruang Kota: Problem Masa Lalu, Masa Kini, dan Masa Depan Perkotaan di Indonesia," Pidato Dies Natalis Universitas Airlangga ke-59 di Surabaya, 11 November 2013. Makalah dapat dilihat pada http://basundoro-fib.web.unair.ac.id/artikel_detail92280-Sejarah-perebutan\%20ruang\%20kota:\%20 problem $\% 20$ masa $\% 201$ alu, $\% 20$ masa $\% 20$ kini, $\% 20$ dan $\% 20$ masa $\% 20$ depan $\% 20$ perkotaan $\% 20$ di $\% 20$ indonesia.html, diakses 2 November 2015.

http://www.datastatistik-indonesia.com/portal/index. php?option=com_content\&task=view\&id=919, diakses 11 Agustus 2013.

\section{Koran}

"Alih Fungsi Lahan Tidak Terpantau," Kompas, 1 Desember 2011.

"Hadang Alih Fungsi Lahan," Kompas, 24 Januari 2012.

"Lahan Pertanian di Jawa Terancam," Kompas, 4 November 2011.

"Pemda Harus Hentikan Alih Fungsi Lahan Pertanian," Kompas, 7 Februari, 2012.

"Segerakan Reforma Agraria," Kompas, 2 Desember 2011. 